\title{
First-hand Accounts of Life in the Trenches
}

\author{
Nathan Grills ${ }^{a}$ and Elliott Larson ${ }^{\mathrm{b}}$
}

\author{
${ }^{a}$ MBBS, MPH, DPhil, Associate Editor, CJGH; Nossal Institute of Global Health, University of Melbourne, Victoria, \\ Australia' \\ ${ }^{\mathrm{b}} \mathrm{MD}, \mathrm{FRCP}$, FIDSA, Editor-in-Chief, CJGH
}

With this issue the editors inaugurate a feature which we hope will be an encouragement and stimulus to further reflection and comment. We are publishing three first person accounts of experiences in what began in each case as the ordinary conduct of work as a physician. All three accounts have been written on-the-fly, so to speak. None of them offer extended reflections on the experience although the experiences might invite such comment. One purpose in publishing them is to stimulate such reflection.

One is the recent first-hand account of a female physician who acquired Ebola from the index case in Nigeria and recovered. The patient from whom she acquired Ebola prevaricated about his Ebola exposure, infecting two physicians and two nursing assistants, three of whom died. By God's grace she is healed. Contributing to this healing is a combination of her knowledge of Ebola, remarkable pastoral concern expressed by her pastorphysician, and a response drawing on local, national and international resources. There is joy in recovery and reunion with loved ones, gratitude for faithful spiritual help and generous medical care, acknowledgement of effective public health intervention and sorrow at the loss of esteemed colleagues.

A second submission describes a circumstance which must be the lot of many missionary doctors, the need to perform a procedure or deal with circumstances beyond one's training and experience, and clearly recognizing God at work in bringing about physical healing. Prior to operating he consults specialist friends via email; a practice that is increasingly utilized in remote mission settings. ${ }^{1}$ Operating with a scalpel in one hand and a surgical textbook in another may not be all that uncommon in medical mission setting. Some find this troubling. Brian Palmer in a recent, widely quoted Slate article questioned the quality and lack of oversight of missionary medicine even while acknowledging its commitment and sacrificial dedication in the face of epidemics like Ebola. ${ }^{2}$ However, there is another aspect to this question which portends a broader perspective. Missionary doctors by-and-large are educated in a conceptually oriented system where they learn the science behind their clinical acumen and are practiced in problem solving. This aspect of their background tends to get lost in an increasing concentration on clinical guidelines and protocols. Equipped with the anatomic, physiologic, and pathologic understanding that is basic to a modern medical education, they are indeed equipped to confront conditions and situations they have never before encountered. Such occasions are yet another challenge to the problem-solving lifestyle for which they have been trained and are called.

The third report from the field takes us from triumph to tragedy. Dealing with complications of labor and childbirth is common in hospitals and in communities throughout the world, especially in underserved areas, and death in childbirth continues to be a tragic accompaniment of these complications. Every day, around 800 women die from preventable causes related to pregnancy and childbirth; $27 \%$ of these die from post-partum hemorrhage. ${ }^{3,4}$ The author of this report examines the challenge to become more spiritually involved with such a patient and her family. There is a sudden and stark realization of the limitations of her technical capacities. Beyond that, what does she have to offer? This is an important milestone in becoming a sensitive and compassionate physician who cares for the whole person.

These three articles touch on central themes in global healthcare: prayer, faith and healing. In the first article God heals one Nigerian Christian from Ebola whist other colleagues die beside her. In the second article God guides the hands of a doctor who is inexperienced in surgery, and the child recovers. In contrast, in the third story a 
young woman tragically passes away despite the care of faithful Christian staff. So where was God in the third case? Did the surgeons not pray hard enough? Did they have little faith?

These situations balance each other. God does guide our hands and decisions in order to physically heal people and he does respond to prayer. However, in his sovereignty he does not always choose to heal physically. God is at work in all three stories but in different ways. The second author alludes to the paradox of God at work: "I honestly felt God was orchestrating the whole thing." Indeed, Jesus physically healed some but not others, and each time it was for his glory.

God heals in all three stories from the field, but in different ways. Where the patient tragically passes away he heals the author by challenging her to show God's love to those who mourn and to attend to the soul. God begins to heal the emotional trauma of the family. And God brings us home through death. The risk of publishing the second story alone is that we can be tempted to measure success merely by prayers answered and physical healing. Health mission is about seeing God at work in life and death, in relief of pain and in suffering, in power and weakness, in physical healing and spiritual healing. We should be aware of not painting a picture of health missions which limits God's power to only physical healing. Health according to the Bible is much more comprehensive than that, to which Apolos Landa's commentary in this issue speaks. Will we trust him as Job did, knowing our Redeemer lives? "The Lord gave, and the Lord has taken away; blessed be the name of the Lord." (Job 1: 21, ESV).

\section{References}

1. Emailing md2ndopinion@aol.com is one telemedicine service available to missionary doctors and another reliable service is the Swinfen Trust.

2. Palmer B. In Medicine We Trust: Should we worry that so many of the doctors treating Ebola in Africa are missionaries? Slate. 2014 Oct 2 [cited 2014 Nov 1] Available at:

http://www.slate.com/articles/health and science/medic al examiner $/ 2014 / 10 /$ missionary doctors treating ebola in_africa_why_people_are_suspicious_of.html

3. WHO. World Health Statistics 2014. Geneva, World Health Organization; 2014 [cited 2014 Nov 1] Available at:

http://apps.who.int/iris/bitstream/10665/112738 /1/9789240692671 eng.pdf?ua=1

4. Say L et al. Global Causes of Maternal Death: A WHO Systematic Analysis. 2014. The Lancet 2 (6): e323-e333 http://dx.doi.org/10.1016/S2214109X(14)70227-X

5. Kassebaum, NJ. Global, regional and national levels and causes of maternal mortality during 19902013: A systematic analysis for the Global Burden of Disease Study 2013. The Lancet 384 (9947): 9801004. http://dx.doi.org/10.1016/S0140$\underline{6736(14) 60696-6}$

www.cjgh.org

Nov 2014. Christian Journal for Global Health, 1(2):5-6. 